\title{
The Impact of Instruction on Iranian Intermediate EFL Learners' Production of Requests in English
}

\author{
Hossein Vahid Dastjerdi \\ English Department, the University of Isfahan, Isfahan, Iran \\ Email: h_vahid@yahoo.com \\ Ehsan Rezvani \\ The University of Isfahan, Isfahan, Iran \\ Email: rezvani_ehsan_1982@yahoo.com
}

\begin{abstract}
The present study investigated the extent to which two instructional paradigms-explicit vs. implicit instruction-affect learners' ability to use the speech act of request in English. Ninety homogenous adult Iranian intermediate EFL learners attending a language school in Isfahan, Iran, were randomly assigned to three groups: Explicit Group (EG), Implicit Group (IG) and Control Group (CG)). A pre-test was given to the three groups to measure the participants' ability to use requests prior to any treatment. Then, all the groups were exposed to short conversations (audio and script) including certain requests. However, while the EG received explicit and deductive instruction by means of direct awareness-raising tasks and metapragmatic explanations, the IG was provided only with typographical enhancement of the request strategies in focus. The students in the CG did not receive any instruction. The results of the post-test, administered after the treatment, indicated that both explicit and implicit instruction exert a significant effect on the learners' production of request strategies in English. It was also found that participants who received explicit instruction outperformed those in the implicit group; however; the observed difference was not statistically significant. Accordingly, it can be claimed that an implicit and unobtrusive method such as input enhancement can be as effective as explicit instruction which requires the execution of various awareness-raising tasks and explanation of metapragmatic information.
\end{abstract}

Index Terms - explicit language instruction, implicit language instruction, pragmatic development, speech acts, requests

\section{INTRODUCTION}

A few decades ago research in interlanguage pragmatics (ILP) focused mainly on the interaction norms employed in different languages and cultures. Mostly, such research aimed at comparing second language (L2) learners' speech act realization with those of native speakers (Kasper, 1989). More recently, however, research findings indicate that there are considerable differences between L2 learners and native speakers with regard to their perception and production of speech acts (Bardovi-Harlig, 2001). Accordingly, the linguistic area of pragmatics in the context of second language acquisition (SLA) has witnessed a surge of interest in studies that examine L2 learners' pragmatic competence in their interlanguage. More specifically, research in the last decade has focused on the role of instruction in pragmatic development (for reviews, see Martinez-Flor et al., 2003; Kasper, 2001; Kasper and Rose, 2002), and it has been found that learners who receive instruction on different aspects of pragmatics are at a distinct advantage (Olshtain and Cohen, 1990; Takahashi, 2001; Rose and Ng Kwai-Fun, 2001, Safont, 2005 among others).

Two main trends are recognizable in research on instructed ILP. One group of studies has placed more emphasis on examining the teachability of pragmatic features, pragmatic routines, conversational implicature, discourse strategies, politeness in requests, as well as speech acts (Billmyer, 1990; Eslami-Rasekh et al., 2004; Fukuya, 1998; Kondo, 2001, 2004; Rose and Ng Kwai-Fun, 2001; Yoshimi, 2001, to mention a few). These studies have employed an explicit focus on forms (FonFS) approach and they have investigated the effects of explicit teaching of pragmatics by providing metapragmatic information. Another group of studies on instructed ILP has focused mainly on comparing the effects of explicit and implicit instruction on L2 pragmatic awareness and development (House, 1996; Pearson, 2001; Takahashi, 2001; Tateyama, 2001, Tateyama et al., 1997).

Following this line of inquiry, the present study aimed at investigating the potential effect of instruction on Iranian EFL learners' production of a certain number of request strategies in English. Moreover, this study sought to compare the facilitative effect of explicit instruction with that of implicit instruction on the production of requests.

\section{BACKGROUND OF THE STUDY}

A. Research on ILP 
Findings of research conducted on the effects of instruction on pragmatics in SLA have indicated positive effects of such efforts (Kasper, 2001). Most of these studies, which employed explicit instruction where learners were provided with explicit meatpragmatic information through explanation, description and discussion of speech acts, have lent support to facilitative effects of explicit instruction (Billmyer, 1990; Takahashi, 2001; Rose and Ng Kwai-Fun, 2001; Tateyama, 2001). In other words, it has been concluded that receiving explicit instruction promotes learners' ability to express more native-like speech acts.

Nevertheless, fewer studies, focused on how implicit instruction leads to pragmatic learning, have presented inconclusive results. For instance, while Martinez-Flor (2004) has demonstrated how L2 learners can benefit from implicit instruction in their pragmatic development, Fukuya and Clark (2001) and Fukuya et al., (1998) have reported insignificant effects of certain types of implicit instruction on pragmatic learning.

\section{B. Implicit vs. Explicit Instruction and Noticing}

Long (1991) has distinguished between focus on form (FonF) and focus on forms (FonFS). In his view, the latter refers to decontextualized, highly metapragmatic, teacher-centered instruction in which the main objective is to assist learners to accumulate individual language items. The former, however, refers to meaning-focused activities in which learner's attention is drawn to target forms as they arise incidentally in the input. In fact, FonFS employs explicit awareness-raising activates, whereas FonF methods such as input enhancement indirectly and unobtrusively draw learners' attention to target forms.

Moreover, an increasingly well-established line of work has underscored the role of noticing and attention in SLA (Schmidt, 1990, 1995, 2001; Tomlin and Villa, 1994; Robinson, 1995). Emphasis has been placed on the legitimacy of a FonF approach to language teaching (Doughty \& Williams, 1998) as well as on the importance of indirectly drawing learners' attention to certain linguistic features which might otherwise go unnoticed (Sharwood Smith, 1991, 1993, 1994). However, since most of these studies have addressed grammatical development, more research is needed on the effect of implicit FonF approaches on pragmatic development. Thus, along the same line of research, this study had an eye on the effects of both explicit and implicit instruction on Iranian EFL learners' production of a certain number of request strategies in English.

\section{RESEARCH QUESTIONS}

The research questions to be investigated and answered were as follows:

1. Does explicit instruction exert a significant impact on Iranian EFL learners' production of linguistically accurate and pragmatically appropriate requests?

2. Does implicit instruction have significant impact on Iranian EFL learners' production of linguistically accurate and pragmatically appropriate requests?

3. Is there a significant difference between explicit and implicit instruction with regard to the influence these two approaches to teaching exert on EFL learners' production of linguistically accurate and pragmatically appropriate requests?

\section{METHOD}

\section{A. Participants}

The participants in this study were 120 Iranian intermediate EFL learners, age 19-27, attending a language center in Isfahan, Iran. In order to make sure in objective terms that these learners were truly homogenous with regard to their English proficiency level, a Nelson English Language Proficiency Test (Fowler and Coe, 1976) was given to them. Having obtained the proficiency test results, the researchers decided to choose those participants whose score range fell one standard deviation above and below the mean (i.e. mean \pm 1 ). This being so, 90 students met this homogeneity criterion and were thus selected to serve as the participants of this study. Later, they were randomly assigned to the three groups (two experimental and one control) involved in the study (30 students each).

\section{B. Instructional Foci}

The instructional foci in this study were ten different structures to perform the speech act of request. These target forms were selected from three English teaching series: New Interchange, $3^{\text {rd }}$ Edition (Richards et al. (2005)); American Headway (Soars and Soars (2001)), and Top Notch (Saslow and Ascher, (2006)). The ten request patterns in focus were classified into two categories according to the sociopragmatic factor of status: ${ }^{1}$

Equal status patterns (equal status between a speaker and the interlocutor) included: Will you open the door?; Can I use your pen?; Could you lend me ten bucks?; Is it OK if I use your pen?; Do you mind if I use your camera?

Higher status pattern (higher status of an interlocutor than that of the speaker) included: Would it be OK if I borrowed your car tomorrow?; Would you mind if I used your cell phone?; Would you mind opening the door?; I wonder if I could borrow some money?; I was wondering if you'd mind lending me your car?

\footnotetext{
${ }^{1}$ The target forms in focus are in italics.
} 


\section{Procedures and Treatment}

The experimental sequence of the study was carried out over a period of around twelve weeks. As noted earlier, 90 homogenous learners were randomly assigned to three groups: an explicit group (EG), an implicit group (IG) and a control group (CG). One week prior to the first treatment session, all the participants took the pre-test which was a tenitem Discourse Completion Task (DCT) designed to elicit the request speech act in different situations and assess the learners' knowledge of these prior to any type of treatment (see Appendix A for sample items of the pre- and the posttest). Then, every group underwent ten different treatment sessions. There was an interval of around 5 or 6 days between the treatment sessions, and the post-test (another DCT with different items) followed the last teaching session a week later. In an attempt to control for outside exposure to the target form, after completing the post-test, the learners were asked whether they had consulted with anyone or anything about the target form. The data from those who reported having done so were discarded. For this reason, the groups slightly differed in size; there were $28,26,25$ participants in EG, IG and CG, respectively.

The instruction for the explicit group was characterized by explicitness and deduction following the principles of a FonFS approach. This group first listened to a short conversation including the requests in focus. Then, they received a scripted version of the conversation, and participated in a series of direct awareness-raising (i.e., listening to teacher's explanations about grammatical rules involved and the metapragmatic information on appropriateness of requests) and productive (i.e., role-plays) activities. In other words, students in EG received explicit instruction on grammatical accuracy of the target forms and metapragmatic information about their appropriate use as well as tasks on the themes in the conversations (see Appendix B for examples of activities used with EG).

The treatment for the implicit group employed a FonF technique-visual input enhancement. After listening to the same conversations, the students in IG received the script in which the target forms (i.e., requests in focus) appeared in bold (See Appendix C for sample excerpts). That is, unlike the EG students for whom the target forms appeared in plain text-type, IG students were provided with typographical enhancement of the target forms. The purpose of using input enhancement was to indirectly draw learners' attention to forms, function and appropriate usage without embarking on explanation about grammar or metapragmaitc information about appropriate use.

Those in the control group listened to the conversations and were provided with the scripts in plain text-type. Needless to say, they received neither implicit nor explicit instruction on requests.

\section{Tests and Scoring Procedure}

Since this study was designed to focus on the pragmatic learning of certain requests by EFL learners after certain types of treatment were employed, a pre-test and a post-test (see Appendix A for sample questions) were constructed by the researchers to assess the participants' knowledge of requests prior to and after the treatment phase of the study. Both tests were DCTs constituting ten different situations to which the students were required to respond by providing a request. It should be noted that the situations in the pre- and post-test were all different and since the pre- and post-test utilized in this study were researcher-made ones, they were both piloted prior to use and an alpha Cronbach method was applied to guarantee their reliability. Reliability indexes revealed that the researcher-made tests were acceptable for the purpose of the study.

Participants' responses to pre- and post-test items (their use of requests) were scored considering the type of language used; that is, each linguistically accurate and pragmatically appropriate request was given a single point. Answers which were grammatical but not pragmatically appropriate or vice versa were given half a point, and answers which were neither grammatical nor appropriate were given zero. All the correct answers added up to a total sum. It should be noted that following Trosborg's proposal (1995) on request realization strategies, the appropriateness of requests was decided upon considering two variables: social distance of the interlocutors and the size of the favor.

\section{Statistical ANALYSiS AND RESUlts}

\section{A. Pre-test of the Study}

For the groups to be comparable and for an experiment like this to be meaningful, the researchers had to make sure that the learners in the experimental and control groups enjoyed the same level of knowledge regarding the linguistic forms under investigation (i.e. request patterns). To meet this requirement, a pre-test was given to all three groups to measure their knowledge of the requests in focus. Table 1 shows the descriptive statistics of the participants' mean scores on the pre-test across the three groups.

TABLE1.

DESCRIPTIVE STATISTICS FOR THE PRE-TEST

\begin{tabular}{|c|c|c|c|c|c|}
\hline & N & Minimum & Maximum & Mean & Std. Deviation \\
\hline EG & 28 & 2.50 & 7.50 & 4.8036 & 1.17331 \\
IG & 26 & 3.00 & 7.00 & 4.8654 & 1.08220 \\
CG & 25 & 3.00 & 7.50 & 4.9400 & 1.10227 \\
Valid N (listwise) & 25 & & & & \\
\hline
\end{tabular}


It can be seen in the above table that the mean scores for the three groups are statistically very close $(4.8036 \approx 4.8654 \approx 4.9400$ ). Therefore, it can be concluded that the learners in the three groups did not differ greatly from one another in terms of their knowledge of the target forms in question. That is, the participants' prior knowledge of the target forms was statistically almost equal.

\section{B. Research Question 1}

The first research question asked whether explicit instruction exerts a significant influence on the acquisition of requests by Iranian intermediate EFL learners. To investigate the impact of explicit instruction on the participants' production of requests, a paired-samples t-test was run. The t-test was intended to compare the obtained mean scores of the participants in EG on the pre- and post-test to indicate the effectiveness of the treatment. The descriptive statistics, along with the results of the t-test for EG, are presented in Tables 2 and 3, respectively.

TABLE 2.

PAIRED SAMPLES DESCRIPTIVE STATISTICS FOR EG

\begin{tabular}{|cc|c|c|c|c|}
\hline & & & & & Std. Error \\
& & Mean & $\mathrm{N}$ & Std. Deviation & Mean \\
\hline Pair 1 & EG Posttest & 7.8393 & 28 & 1.16312 & .21981 \\
& EG Pretest & 4.8036 & 28 & 1.17331 & .22173 \\
\hline
\end{tabular}

TABLE 3.

PAIRED SAMPLES T-TEST RESULTS FOR EG

\begin{tabular}{|c|c|c|c|c|c|c|c|c|}
\hline & \multicolumn{5}{|c|}{ Paired Differences } & \multirow[b]{3}{*}{$\mathrm{t}$} & \multirow[b]{3}{*}{ df } & \multirow{3}{*}{$\begin{array}{c}\text { Sig. (2- } \\
\text { tailed) }\end{array}$} \\
\hline & \multirow[b]{2}{*}{ Mean } & \multirow[b]{2}{*}{ Std. Deviation } & \multirow{2}{*}{$\begin{array}{l}\text { Std. Error } \\
\text { Mean }\end{array}$} & \multicolumn{2}{|c|}{$\begin{array}{l}\text { 95\% Confidence } \\
\text { Interval of the } \\
\text { Difference }\end{array}$} & & & \\
\hline & & & & Lower & Upper & & & \\
\hline $\begin{array}{ll}\text { Pair } & \text { EG Posttest } \\
1 & \text { EG Pretest }\end{array}$ & 3.03571 & 1.50264 & .28397 & 2.45305 & 3.61838 & 10.690 & 27 & .000 \\
\hline
\end{tabular}

Given the information in Table 2, one can clearly see that the mean score obtained on the post-test (7.8393) is higher than the one obtained on the pre-test (4.8036). However, a paired-samples t-test was run to ensure that the observed difference was significant. Table 3 shows that there is a significant difference in the scores obtained from the pre- and post-test because the probability value is substantially smaller than the specified critical value $(0.000<0.05)$. Accordingly, it can be claimed that explicit instruction was shown to exert a positive effect on the acquisition of the given requests.

\section{Research Question 2}

The second research question asked whether input enhancement has a significant effect on the acquisition of requests by Iranian intermediate EFL learners. To answer this question, a paired-samples t-test was conducted. Tables 4 and 5 provide the descriptive statistics, along with the results of the given paired-samples t-test.

TABLE 4.

PAIRED SAMPLES DESCRIPTIVE STATISTICS FOR IG

\begin{tabular}{|c|c|c|c|c|c|}
\hline & & Mean & $\mathrm{N}$ & Std. Deviation & $\begin{array}{c}\text { Std. Error } \\
\text { Mean }\end{array}$ \\
\hline \multirow[t]{2}{*}{ Pair 1} & IG Posttest & 7.5962 & 26 & 1.00019 & .19615 \\
\hline & IG Pretest & 4.8654 & 26 & 1.08220 & .21224 \\
\hline
\end{tabular}

TABLE 5.

PAIRED SAMPLES T-TEST RESULTS FOR IG

\begin{tabular}{|c|c|c|c|c|c|c|c|c|c|}
\hline & & \multicolumn{5}{|c|}{ Paired Differences } & \multirow[b]{2}{*}{$\mathrm{t}$} & \multirow[b]{2}{*}{$\mathrm{df}$} & \multirow[b]{2}{*}{$\begin{array}{l}\text { Sig. }(2- \\
\text { tailed) }\end{array}$} \\
\hline & & Mean & Std. Deviation & $\begin{array}{c}\text { Std. Error } \\
\text { Mean }\end{array}$ & $\begin{array}{r}95 \% \text { Con } \\
\text { of the }\end{array}$ & $\begin{array}{l}\text { ice Interval } \\
\text { ference }\end{array}$ & & & \\
\hline Pair 1 & $\begin{array}{l}\text { IG Posttest } \\
\text { IG Pretest }\end{array}$ & 2.73077 & 1.21021 & .23734 & 2.24195 & 3.21958 & 11.506 & 25 & .000 \\
\hline
\end{tabular}

On a closer inspection of the mean scores given in Table 4, one can clearly see that the participants in IG gained a higher mean score on the post-test after receiving the treatment (Pos-test=7.5962>Pre-test=4. 8654). However, the 
researchers had to go further to find out whether or not the observed difference was significant. Therefore, the results of the t-test were taken into account. It can be concluded from the information presented in Table 5 that there is a significant difference in the performance of the participants on the pre- and post-test. This conclusion can be drawn because the probability value in Table 5 is observed to be 0.000 which is less than the critical value (0.05). In sum, it can be maintained that input enhancement has a positive impact on the Iranian intermediate EFL learners' production of requests.

\section{Research Question 3}

The last research question asked whether there is a significant difference between explicit methods of instruction and input enhancement as an implicit method of instruction with regard to the influence these two approaches to teaching exert on the production of certain request patterns by Iranian intermediate EFL learners. The descriptive statistics of the scores obtained from the post-test demonstrate that the members of the experimental groups (EG and IG) outperformed those of the control group (CG). In fact, one can see in Table 6 that the mean score obtained by EG (7.8393) exceeds the mean score obtained by IG (7.5962) which is, in turn, higher than the mean score belonging to CG (5.1600).

TABLE 6.

DESCRIPTIVE STATISTICS FOR THE POST-TEST

\begin{tabular}{|c|c|c|c|c|c|}
\hline & N & Minimum & Maximum & Mean & Std. Deviation \\
\hline EG & 28 & 6.00 & 10.00 & 7.8393 & 1.16312 \\
IG & 26 & 6.00 & 9.00 & 7.5962 & 1.00019 \\
CG & 25 & 3.00 & 8.00 & 5.1600 & 1.43411 \\
Valid N (listwise) & 25 & & & & \\
\hline
\end{tabular}

Having gained some rudimentary information about the differences in the performance of the members of the three groups on the post-test, the researchers had to determine whether or not the observed differences were significant at the critical value (Sig.) of $\mathrm{p}<0.05$. Therefore, a one-way between-groups ANOVA was conducted. Table 7 provides the results of the ANOVA.

TABLE 7.

THE RESULTS OF ANOVA ON THE POST-TEST

\begin{tabular}{|c|c|c|c|c|c|}
\hline & $\begin{array}{c}\text { Sum of } \\
\text { Squares }\end{array}$ & df & Mean Square & F & Sig. \\
\hline Between Groups & 114.862 & 2 & 57.431 & 40.346 & .000 \\
Within Groups & 108.182 & 76 & 1.423 & & \\
Total & 223.044 & 78 & & & \\
\hline
\end{tabular}

On a closer inspection of Table 7, one can conclude that the three groups differed significantly with respect to their mean scores on the post-test because the significant value is observed to be 0.000 , which is less than the critical value (0.05). Although the information presented in Table 7 is very revealing, it does not show where the observed differences lie. The researchers, therefore, had to run a Scheffe Post-hoc test. This post-hoc test indicates where the differences among the three groups (i.e. sets of scores) occur. Table 8 provides the results of the post-hoc test.

TABLE 8.

THE RESUlTS OF THE POST-HOC TEST

\begin{tabular}{|c|c|c|c|c|c|c|}
\hline \multirow[b]{2}{*}{ (I) Groups } & \multirow[b]{2}{*}{ (J) Groups } & \multirow{2}{*}{$\begin{array}{c}\text { Mean } \\
\text { Difference } \\
(\mathrm{I}-\mathrm{J})\end{array}$} & \multirow[b]{2}{*}{ Std. Error } & \multirow[b]{2}{*}{ Sig. } & \multicolumn{2}{|c|}{$95 \%$ Confidence Interval } \\
\hline & & & & & Lower Bound & Upper Bound \\
\hline \multirow[t]{2}{*}{ EG } & IG & .27885 & .32494 & .693 & -.5325 & 1.0902 \\
\hline & CG & $2.71500 *$ & .32829 & .000 & 1.8953 & 3.5347 \\
\hline \multirow[t]{2}{*}{ IG } & EG & -.27885 & .32494 & .693 & -1.0902 & .5325 \\
\hline & CG & $2.43615 *$ & .33419 & .000 & 1.6017 & 3.2706 \\
\hline \multirow[t]{2}{*}{ CG } & EG & $-2.71500 *$ & .32829 & .000 & -3.5347 & -1.8953 \\
\hline & IG & $-2.43615 *$ & .33419 & .000 & -3.2706 & -1.6017 \\
\hline
\end{tabular}

*. The mean difference is significant at the .05 level. 
As mentioned above, the post-hoc test was employed to show where exactly the differences lie. In the above table, where there is an asterisk $(*)$ next to the values listed in the second column, this means that the groups being compared are significantly different from one another at the $p<0.05$ level. In the first row of the table, the asterisk next to 2.71500 indicates that the difference between EG and CG is significant. Likewise, the difference between IG and CG appears to be significant because an asterisk can be seen next to 2.43615 in the second row of the table. In a nutshell, it can be claimed that CG is significantly different from EG and IG, but there seems to be no significant difference between EG and IG. As a result, it can be claimed that there is no significant difference between explicit and implicit instruction in terms of the influence they exert on the production of requests.

\section{DISCUSSION}

This study was an attempt to investigate three research questions: (1) whether explicit instruction exerts a significant influence on the production of requests by Iranian intermediate EFL learners; (2) whether implicit instruction (input enhancement, in particular) has a significant effect on the production of requests by Iranian intermediate EFL learners; and (3) whether there is a significant difference between explicit and implicit instruction with regard to the influence these two approaches to teaching exert on the production of requests by Iranian intermediate EFL learners. In brief, it was revealed that both explicit and implicit instruction have a positive impact on the acquisition of the target forms. Moreover, the findings indicated that these two methods were not significantly different with regard to the influence they exert on the acquisition of the target forms.

Firstly, the fact that learners who received explicit instruction did significantly better on the post-test suggests that explicit instruction was effective in leading learners to produce linguistically accurate and pragmatically appropriate requests. This is in line with previous studies that report the benefits of explicit instruction for L2 pragmatic development (Billmyer, 1990; Bouton, 1994; Rose and Ng Kwai-fun, 2001; Safont, 2003, 2004, 2005; Takahashi, 2001) More specifically, findings with regard to the first research question in this study lend further support to those studies on the positive effects of explicit instruction which employed explanation and discussion of rules as their approach to provide learners with metapragmatic information (Kubota, 1995; LoCastro, 1997; Trosborg, 2003; Yoshimi, 2001; Wishnoff, 2000). The present study, in line with the aforementioned studies, concludes that learners' ability to express more native-like speech acts will improve with explicit instruction, although whether or not that knowledge is retained over time is questionable. Moreover, the significant improvement of the EG in the production of requests in this study can be justified considering Bialystok's position (1993) on two cognitive components of language processing — analysis of knowledge and control of processing. Since EG learners received explicit explanation of rules regarding both accuracy and appropriateness of requests, their pragmatic knowledge must have been developed in terms of metalinguistic knowledge and the relations between forms and appropriate use.

Secondly, the results demonstrating that the learners who received implicit instruction made significant gains with regard to the production of requests concurs with the general findings in earlier studies on the facilitative effects of input enhancement (Shook, 1994; Doughty, 1991; Leeman et al., 1995; Williams, 1999). Studies on the effects of implicit instruction on L2 learners' pragmatic development have produced mixed results. Fukuya et al. (1998) reported that implicit instruction was not efficient in comparison with explicit instruction. However, the present findings lend further support to those studies which have demonstrated the positive effects of input enhancement on the acquisition of speech acts (Fukuya and Clark, 2001; Martinez-Flor, 2004; Alcon, 2005).

Thirdly, in relation to the effects of explicit versus implicit instruction on learners' production of request, it should be noted that the present findings run counter to those of several other studies (House and Casper, 1981; Takahashi, 2001; Rose and Ng Kwai-Fun, 2001; Alcon, 2005) which have reported that the EG has had an advantage over the IG. In line with the results reported by Martinez-Flor (2004), this study revealed that those students who received explicit instruction outperformed those in the implicit group; however; the observed difference was not statistically significant. Accordingly, it can be claimed that an implicit and unobtrusive method such as input enhancement can be as effective as explicit instruction which requires the execution of various awareness-raising tasks and explanation of metapragmatic information.

\section{CONCLUDING REMARKS}

This study examined the effects of instruction on learners' linguistically accurate and pragmatically appropriate production of certain requests in English. The results contribute to previous research on the facilitative effects of instruction on second and foreign language learning in general (Norris and Ortega, 2000; Doughty, 2003), and the benefits of instruction on the development of learners' pragmatic competence in requests in particular. In light of the present findings which reveal that an implicit method of instruction can be as effective as an explicit one in teaching requests, certain pedagogical implications may be proposed. First, a more direct link should be made between ILP research and the field of second language acquisition. In other words, materials developers and instructors should integrate pragmatics into their second and foreign language instruction to better develop learners' pragmatic competence in second and foreign language settings. Second, awareness-raising tasks and input enhancement 
techniques should be operationalized and implemented by language instructors to equip learners with a better knowledge of pragmatics.

\section{APPENDIX A. SAMPLE SiTUATIONS FROM THE DCT PRE-/POST-TEST}

Write a dialogue for each of the following situations. In each situation you are making a request to a specific person and you are asking different types of favors.

Situation A: You are in class and you want to borrow your friend's notes.

Situation B: You are going on a trip and you can't take your pet with you. You want to ask your friend's parents to take care of him. You know they don't like animals.

Situation $C$ : You are in class. You really need the bathroom and you ask your teacher for permission to leave the class.

Situation D: You need to take some photos on your brother's birthday and you want to borrow your friend's digital camera.

Situation E: You want one of your professors at university to extend his deadline for a term project. You know he is not a good-tempered person.

\section{APPENDIX B. EXAMPLES OF SOME OF THE ACTIVITIES USED WITH THE EG}

Sample teacher's explanation of rules on how to make linguistically accurate and pragmatically appropriate requests:

Modals 'can' and 'could' are used with a following base verb to make a request. They are usually used when one of the interlocutors is higher in position or they know each other very well. For example, in excerpt A, in making his request, Jack says: "Can you lend me a couple of dollars?", which shows that he knows Bill very well.

The structure "Would it be OK if...." is followed by an if-clause containing a past tense verb. It is usually used when one of the interlocutors tries to be more formal and polite because either the favor is a big one or s/he doesn't know the other person well. For instance, in excerpt B, Mary needs to borrow his friend's car, so she says: "Would it be OK if I borrowed your car for the weekend?".

Sample productive activities undertaken by the EG learners after teacher's explanations:

Play the roles of a clerk and her boss. She wants to take a week off from work and needs to make a request and get her boss's permission.

Write a short dialogue making a request for the following situation: "A teacher wants one of her students to open the class window".

\section{APPENDIX C. SAMPLE EXCERPT OF SCRIPTS WITH TYPOGRAPHICALLY ENHANCED INPUT USED WITH THE IG.}

Conversation on the phone:

Rod: Hello.

Jana: Hi, Rod. This is Jana.

Rod: oh, hi Jana. What's up?

Jana: I'm' going to my best friend's wedding this weekend. I'd love to take some pictures for his Website. Would you mind if I borrowed your digital camera?

Rod: Um, no. That's OK, I guess.

Jana: Thanks. Is it OK if I pick it up on Friday night?

\section{REFERENCES}

[1] Alcon, E. (2005). Does instruction work for learning pragmatics in the EFL context? System 33, pp. 417-435.

[2] Bardovi-Harlig, K. (2001). Evaluating the empirical evidence: grounds for instruction in pragmatics. In K.R. Rose \& G. Kasper (Eds.), Pragmatics in Language Teaching. Cambridge University Press, Cambridge, pp. 13-32.

[3] Bialystok, E. (1993). Symbolic representation and attentional control in pragmatic competence. In G. Kasper \& S. Blum-Kulka (Eds.), Interlanguage Pragmatics. Oxford University Press, Oxford, pp. 43-57.

[4] Billmyer, K. (1990). "I really like your lifestyle": ESL learners learning how to compliment. Penn Working Papers in Educational Linguistics 6 (2), 31-48.

[5] Bouton, L.F. (1994). Can NNS skill in interpreting implicature in American English be improved through explicit instruction? -A pilot study. In L. Bouton (Ed.), Pragmatics and Language Learning, vol. 5. Division of English as an International Language Intensive English Institute, University of Illinois at Urbana-Champaign, Urbana, IL, pp. 88-109.

[6] Doughty, C. (1991). Second language instruction does make a difference: evidence from an empirical study of SL relativization. Studies in Second Language Acquisition 13 (4), 431-469.

[7] Doughty, C. (2003). Instructed SLA: Constraints, compensation, and enhancement. In C. Doughty \& M.H. Long (Eds.), The Handbook of Second Language Acquisition. Blackwell, Oxford, pp. 256-310.

[8] Doughty, C. \& J. Williams (1998). Focus on Form in Classroom Second Language Acquisition. Cambridge University Press, Cambridge. 
[9] Eslami-Rasekh, Z., A. Eslami-Rasekh \& A. Fatahi. (2004). The effect of explicit metalinguistic instruction on the speech act awareness of advanced EFL students. TESL-EJ 8 (2), 1-12. Available from: http://cwp60.berkeley.edu:16080/TESLEJ/ej30/a2.html.

[10] Fowler, W. S. \& N. Coe. (1976). Nelson English Language Tests. Bulter and Tannerltad, London.

[11] Fukuya, Y.J. (1998). Consciousness-raising of downgraders in requests. Paper Presented at Second Language Research Forum '98, University of Hawai'i at Manoa (ERIC Document Reproduction Service No. ED466100).

[12] Fukuya, Y.J., M. Reeve, J. Gisi, \& M. Christianson. (1998). Does focus on form work for teaching sociopragmatics? Paper Presented at the 12th International Conference on Pragmatics and Language Learning, University of Illinois at UrbanaChampaign (ERIC Document Reproduction Service No. ED 452736).

[13] Fukuya, Y.J. \& M.K. Clark. (2001). A comparison of input enhancement and explicit instruction of mitigators. In L. Bouton (Ed.), Pragmatics and Language Learning, vol. 10. Division of English as an International Language Intensive English Institute, University of Illinois at Urbana-Champaign, Urbana, IL, pp. 111-130.

[14] House, J. (1996). Developing pragmatic Xuency in English as a foreign language. Studies in Second Language Acquisition 18 , $225-253$.

[15] House, J. \& G. Kasper. (1981). Politeness markers in English and German. In F. Coulmas (Ed.), Conversational Routine. Mouton de Gruyter, The Hague, The Netherlands, pp. 157-185.

[16] Kasper, G. (1989). Variation in interlanguage speech act realisation. In S. Gass, C. Madden, D. Preston \& L. Selinker (Eds.), Variation in second language acquisition, Discourse and Pragmatics, vol. 1. Multilingual Matters, Clevedon, Avon, pp. 37-58.

[17] Kasper, G. (2001). Classroom research on interlanguage pragmatics. In K.R. Rose \& G. Kasper (Eds.), Pragmatics in Language Teaching. Cambridge University Press, Cambridge, pp. 33-60.

[18] Kasper, G. \& K.R. Rose. (2002). Pragmatic Development in a Second Language. Blackwell, Mahwah, NJ.

[19] Kondo, S. (2001). Instructional eVects on pragmatic development: refusal by Japanese EFL learners. Publications of Akenohoshi Women's Junior College 19, 33-51.

[20] Kubota, M. (1995). Teachability of conversational implicature to Japanese EFL learners. The Institute for Research in Language Teaching Bulletin 9, 35-67.

[21] Leeman, J., I. Arteagoitia, B. Fridman \& C. Doughty. (1995). Integrating attention to form with meaning: focus on form in content-based Spanish instruction. In R. Schmidt (Ed.), Attention and Awareness in Foreign Language Learning. University of Hawai'i, Second Language Teaching \& Curriculum Center, Honolulu, HI, pp. 217-258.

[22] LoCastro, V. (1997). Pedagogical intervention and pragmatic competence development. Applied Language Learning 8 (1), 75 109.

[23] Long, M. H. (1991). Focus-on-form: A design feature in language methodology. In K. De Bot, R. Grinsberg \& D. Kramsch (eds.), Foreign Language Research in Cross-cultural Perspective. John Benjamins, Amsterdam pp. 39-52.

[24] Martínez-Flor, A. (2004). The effect of instruction on the development of pragmatic competence in the English as a foreign language context: a study based on suggestions. Doctoral dissertation, Universitat Jaume I, Castellón, Spain.

[25] Martínez-Flor, A., E. Usó \& A. Fernández. (2003). Pragmatic Competence and Foreign Language Teaching, Servei de Publicacions de la Universitat Jaume I, Castellón, Spain.

[26] Norris, J. \& L. Ortega. (2000). Effectiveness of L2 instruction: a research synthesis and quantitative metaanalysis. Language Learning 50 (3), 417-528.

[27] Olshtain, E. \& A.D. Cohen. (1990). The learning of complex speech act behavior. TESL Canada Journal 7 (2), $45-65$.

[28] Pearson, E.L. (2001). Pragmatics in foreign language teaching: the effects of instruction on L2 learners' acquisition of Spanish expressions of gratitude, apologies, and directives. Unpublished doctoral dissertation, The University of Texas at Austin.

[29] Richards, J. C., J. Hull \& S. Proctor. (2005). Interchange Series, $3^{\text {rd }}$ Edition. Cambridge University Press, Cambridge.

[30] Robinson, P. (1995). Attention, memory, and the "Noticing” hypothesis. Language Learning 45, $283-331$.

[31] Rose, K.R. \& C.K. Ng. (2001). Inductive and deductive teaching of compliments and compliment responses. In K.R. Rose \& G. Kasper (Eds.), Pragmatics in Language Teaching. Cambridge University Press, Cambridge, pp. 145-170.

[32] Safont, M.P. (2003). Instructional effects on the use of request acts modification devices by EFL learners. In A. Martínez-Flor, E. Usó \& A. Fernández (Eds.), Pragmatic Competence and Foreign Language Teaching, Servei de Publicacions de la Universitat Jaume I, Castellón, Spain, pp. 211-232.

[33] Safont, M.P. (2004). An analysis on EAP learners' pragmatic production: a focus on request forms. Ibérica 8, 23-39.

[34] Safont, M.P. (2005). Third Language Learners. Pragmatic Production and Awareness. Multilingual Matters, Clevedon.

[35] Saslow, J. \& A. Ascher. (2006). Top Notch Series. Pearson education, New York.

[36] Schmidt, R. (1990). The role of consciousness in second language learning. Applied Linguistics 112, 129-158.

[37] Schmidt, R. (1995). Consciousness and foreign language learning: a tutorial on the role of attention and awareness in learning. In R. Schmidt (ed.), Attention and awareness in foreign language learning. Second language teaching and curriculum center, Honolulu, pp. 1-63.

[38] Schmidt, R. (2001). Attention. In P. Robinson (ed.), Cognition and second language instruction, Cambridge University Press, Cambridge, pp. 3-32.

[39] Sharwood Smith, M. (1991). Speaking to many minds: On the relevance of different types of language information for the L2 learner. Second Language Research 7, 118-132.

[40] Sharwood Smith, M. (1993). Input enhancement in instructed SLA. Studies in Second Language Acquisition 15, 165-179.

[41] Sharwood Smith, M. (1994). Second language learning: Theoretical foundations. Longman, New York.

[42] Shook, D. (1994). FL/L2 reading, grammatical information, and input-to-intake phenomenon. Applied Language Learning 5, $57-93$

[43] Soars, L. \& J. Soars. (2001). American Headway Series. Oxford University Press, Oxford.

[44] Takahashi, S. (2001). The role of input enhancement in developing pragmatic competence. In K.R. Rose \& G. Kasper (Eds.), Pragmatics in Language Teaching, Cambridge University Press, Cambridge, pp. 171-199. 
[45] Tateyama, Y. (2001). Explicit and implicit teaching of pragmatics routines: Japanese sumimasen. In K.R. Rose \& G. Kasper (Eds.), Pragmatics in Language Teaching. Cambridge University Press, Cambridge, pp. 200-222.

[46] Tateyama, Y., G. Kasper, L.P. Mui, H. Tay \& O. Thananart. (1997). Explicit and implicit teaching of Japanese pragmatics routines. In L. Bouton (Ed.), Pragmatics and Language Learning, vol. 8. Division of English as an International Language Intensive English Institute, University of Illinois at Urbana- Champaign, Urbana, IL, pp. 163-177.

[47] Tomlin, R. \& V. Villa. (1994). Attention in cognitive science and SLA. Studies in Second Language Acquisition 16, $185-204$.

[48] Trosborg, A. (1995). Interlanguage pragmatics. Requests, complaints and apologies. Mouton de Gruyter, Berlin.

[49] Trosborg, A. (2003). The teaching of business pragmatics. In A. Martínez-Flor, E. Usó \& A. Fernández (Eds.), Pragmatic Competence and Foreign Language Teaching, Servei de Publicacions de la Universitat Jaume I, Castellón, Spain, pp. $247-281$.

[50] Williams, J. (1999). Memory, attention, and inductive learning. Studies in Second Language Acquisition 21, 1-48.

[51] Wishnoff, R.J. (2000). Hedging your bets: L2 learners' acquisition of pragmatic devices in academic writing and computermediated discourse. Second Language Studies 19, 119-157. Available from: http://www.hawaii.edu/sls/uhwpesl/online cat.html.

[52] Yoshimi, D.R. (2001). Explicit instruction and JFL learner's use of interactional discourse markers. In KR. Rose \& G. Kasper (Eds.), Pragmatics in Language Teaching. Cambridge University Press, Cambridge, pp. 223-244.

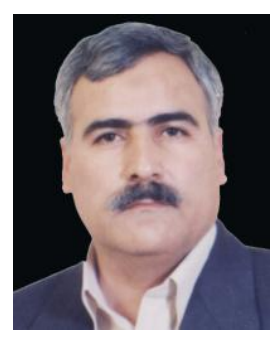

Hossein Vahid Dastjerdi (b. 1955, Isfahan, Iran) teaches in the English Language Department at the University of Isfahan, Iran. He is associate professor of applied linguistics and has taught courses of variegated character, including translation courses, for years. He has been a fellow of the English Centers at the universities of Isfahan and Shiraz where he has investigated into issues related to materials preparation for GE. and ESP. courses. He is the author of a number of books in this respect. He has also published a good number of articles on discourse, testing and translation in local and international journals.

Dr. Vahid's current research interests include testing, materials development, translation, the metaphoricity of language, discourse analysis, pragmatics and critical discourse analysis. He is presently involved in a number of projects concerning translation studies as well as figurative language use.

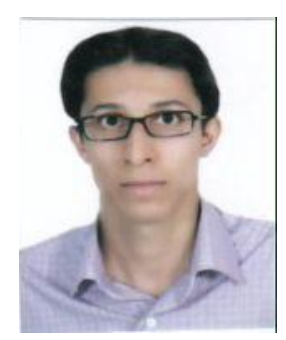

Ehsan Rezvani (b. 1982, Isfahan, Iran) is currently a Ph. D. candidate at the University of Isfahan, Isfahan, Iran. He received his M.A. in TEFL at the University of Isfahan (2007) following the completion of his B.A. in English Translation from Azad University of Khorasgan, Isfahan, Iran (2005). His main research areas of interest are: Second Language acquisition, Language Teaching Methodology, Discourse Analysis and Pragmatics. He has been working as an EFL instructor since 2000. 